\title{
Impact of monetary incentives on teacher retention in and attraction to rural primary schools: Case of the rural allowance in Salima District of Malawi
}

\author{
Denis B. Mwenda and Victor Y. Mgomezulu* \\ Mzuzu University, Private Bag 201, Mzuzu, Malawi. \\ Accepted 20 June, 2018
}

\begin{abstract}
The study attempted to examine the extent to which a rural allowance makes primary school teachers remain in rural schools and attract them from urban to the rural schools of Salima District. A Likert Scale questionnaire was used to collect data from 333 participants, comprising 250 teachers from rural schools and 83 teachers from urban schools. The researcher used Statistical Package for the Social Sciences to analyse the data. The study found that the current amount of rural allowance was inadequate incentive to attract teachers already serving in rural schools to remain there and also attract teachers presently in urban schools to go to rural schools. To attract teachers from urban to rural schools and to make those in rural schools to remain there, the study recommended that different degrees of ruralness should be incentivized according to the level of hardship. Further, the education authorities should introduce additional incentives to alleviate the hardship that teachers experience in rural schools. Moreover, schools should be allowed to recruit teachers that are interested to work in rural schools.
\end{abstract}

Keywords: Attraction, incentives, retention, rural allowance, teachers.

*Corresponding author. Email: mgomezulu@hotmail.com, mgomezulu.v@mzuni.ac.mw.

\section{INTRODUCTION}

Education is the driving force behind the socio-economic development of any nation. It is, therefore, imperative that governments provide equitable access to quality education to all its citizens to enable the majority to participate in the national development agenda. Teachers are the human capital that is central in servicing the education system. It is however, discomforting as Wallace and Sartono (2010) note that in most developing countries some sections of the education sector do not have enough teachers. According to them, the impact of teacher shortage is felt disproportionately by the poorest and most marginalised rural schools. Similarly, UNICEF (2014) observes that in many African and South Asian countries, teachers prefer to teach in urban areas. As a result of high preference for urban schools, rural schools are left with inadequate number of teachers.

A number of studies reveal some of the factors that compel teachers to prefer urban to rural areas. Wallace and Sartono (2010) point out that push-pull and personal factors contribute to teacher attrition in rural schools. Miller (2012) generalises that poor social amenities such as shopping venues and housing make teacher retention in rural schools a challenge. Given that there is limited information on teacher retention that comes directly from the affected teachers in hard to reach rural areas in Africa (UNICEF, 2014), and in a rural district in Malawi in particular, this study sets out to examine the dynamics at play that may be location specific. This study focuses on how monetary incentive impacts on teacher retention in and attraction to rural schools in Malawi. In this connection, the study now examines a few related case studies.

\footnotetext{
Case studies of monetary incentives for teachers in rural schools
}

Many developing countries have put in place 
mechanisms to ensure supply of quality education for rural masses through introduction of monetary incentives to attract teachers to remote areas. One of the popular mechanisms is the hardship allowance.

\section{Hardship allowance in Gambia}

The growing concern over the wide discrepancies in distribution of teachers between rural and urban areas prompted the Gambian Government in 2005 to introduce hardship allowance. Pugatch and Schroeder (2013), report that the Gambian Government provides a salary premium of $30-40 \%$ of monthly salary to primary school teachers in remote locations. To identify the beneficiary schools, the policy targets schools that are located more than $3 \mathrm{~km}$ from a main road and capital city as reference points. The percentages for the allowances increase with increasing distance from the city, in the order of 30,35 and $40 \%$ of the basic salary.

Pugatch and Schroeder (2013) reported that the hardship allowance in Gambia increased the share of qualified teachers in rural schools by $10 \%$ and reduced qualified teacher-pupil ratio by $61 \%$. The hardship allowance as implemented in Gambia proves to be a strong pull factor of teachers to rural school.

While in Gambia hardship allowance is calculated as a percentage of salary depending on distance from the capital and main road, in Malawi the incentive is a flat rate of $K 10,000$ regardless of the degree of distance from urban areas or the qualification of a teacher. The Gambian policy recognises that ruralness can vary in terms of shortage of social amenities while in Malawi ruralness is regarded as homogeneous.

\section{Hardship allowance in Lesotho}

Lesotho has some very mountainous areas where movement is difficult, infrastructure is poor, sparsely populated and the climate is inhospitable. The conditions in these areas make it hard to attract teachers, let alone qualified teachers. There are only $24 \%$ unqualified teachers in the lowlands against $51 \%$ in mountain areas (Mulkeen and Chen, 2008).

Mulkeen (2005) points out that Lesotho uses local hire system to recruit teachers, whilst Malawi uses the centralised system. In the local hire system, a school has the authority to hire the teachers of its choice. This implies that teachers have a choice of the school where they can apply for a teaching post. This leaves the less preferred schools with a limited number of qualified applicants, as most applicants would wish to apply to urban schools. This leads to discrepancy in the distribution of qualified teaching staff between urban and rural schools. In an effort to minimise the inequality in teacher distribution, the Government of Lesotho introduced hardship allowance in hard-to-staff mountainous areas. According to Mulkeen and Chen (2008), Lesotho pays hardship allowance on a flat rate basis regardless of qualification and variations in the degree of ruralness.

Lesotho government gives a hardship allowance of 275 Maloti (\$23 at the rate of 12 Lotis to \$) per month. The surprising report is that there is no substantial evidence indicating retention and attraction of teachers in the hard-to-staff areas (Mulkeen and Chen, 2008).

\section{Location bonus in Mozambique}

In Mozambique location bonus is paid based on grade and degree of ruralness. Since the bonus is calculated as a percentage of salary, it varies with grade and location. Areas are classified into four regions as follows; group 1: major cities, group 2: provincial towns, group 3: more remote villages and group 4: most remote schools. Table 1 depicts the distribution (Mulkeen and Chen, 2008).

Table 2 shows that those at a higher grade consistently receive a higher percentage within the same region. It further indicates that teachers teaching in the most remote areas get the biggest percentage of the location bonus. Unfortunately, little literature documentation has been done on the effect of the location bonus to determine the extent to which the bonus achieved its purpose to locate teachers to rural schools (Mulkeen and Chen, 2008).

In response to rural-urban teacher distribution imbalance, the Government of Malawi too has been compelled to embark on a number of strategies to eliminate the inequality in teacher supply. Among such strategies is the use of monetary incentives known as rural allowance. In 2010, Ministry of Education Science and Technology (MoEST) in Malawi introduced K5,000 as a special allowance for teachers teaching in rural schools (Malawi Government, 2011). Reports indicate that 37,562 teachers across the country received rural allowance of MK 5,000 each, per month. Rural allowance was raised to $\mathrm{K} 10,000$ in January 2014 to redress inflation and attract more teachers (Malawi Government, 2011).

The authority to identify rural and urban schools is vested in the office of the District Education Manager (DEM) for each education district. The criterion for determining a rural school is largely guided by the absence of social amenities such as banks, post office, portable water supply, reliable public hospital and shops. The quality of these amenities differs from one district to another depending on its socio-economic status. What is termed poor for a particular area might be good in another area, thus a universally acceptable definition of ruralness is not achievable as Miller (2012) acknowledges. Due to lack of a universal definition of a rural area, some teachers regard their schools as rural 
Table 1. Staffing levels according to schools' statistical staff returns.

\begin{tabular}{lcccccc}
\hline \multirow{2}{*}{ School } & \multicolumn{7}{c}{ Year and staffing level } \\
\cline { 2 - 7 } & $\mathbf{2 0 0 9}$ & $\mathbf{2 0 1 0}$ & $\mathbf{2 0 1 1}$ & $\mathbf{2 0 1 2}$ & $\mathbf{2 0 1 3}$ & $\mathbf{2 0 1 4}$ \\
\hline Chipoka 1 $^{*}$ & 16 & 16 & 15 & 16 & 18 & 21 \\
Chipoka II* $_{\text {Msumwa }}^{10}$ & 10 & 10 & 20 & 23 & 22 \\
Kambiri & 5 & 7 & 8 & 9 & 9 & 9 \\
Mtiya & 5 & 8 & 8 & 11 & 14 & 14 \\
\hline
\end{tabular}

Key: Schools with * did not benefit from rural allowance scheme because they were deemed to be urban.

Table 2. Incentive payment for teachers, by location, 2005 (percentage of salary).

\begin{tabular}{lcccc}
\hline Teacher qualification & Group 1 & Group 2 & Group 3 & Group 4 \\
\hline Graduate teaching at secondary level & 60 & 70 & 80 & 100 \\
Graduate teaching at upper primary level & 30 & 40 & 50 & 60 \\
\hline
\end{tabular}

Source: Mozambique, Ministry of Education data in Mulkeen and Chen (2008: 93).

and claim to deserve the allowance. For example, Kulemeka and Ndalama (2013) report that teachers in Lilongwe boycotted classes to force MoEST to include them on the rural allowance scheme, while the District Education Manager could not decisively determine whether their schools were in urban or rural.

\section{Statement of the problem}

Ministry of Education in Malawi introduced teachers' rural allowance with the aim of retaining and attracting teachers to the rural schools. A survey conducted in Chipoka Education Zone in Salima District to check the staffing trends, reveals a continued dominance in staffing in urban primary schools over rural primary schools. The survey was conducted by collecting and analyzing data from statistical staff returns for selected schools in Chipoka Education Zone for the month of December from 2009 to 2014. Results of the survey were tabulated as in Table 2.

The results from this survey (Table 1) portray the complexity to attribute the changes in staffing levels to rural allowance only. From the results it is difficult to ascertain the relationship between rural allowance and its influence on teacher retention in and attraction to rural schools due to the following observations:

1. Chipoka I and Chipoka II primary schools, at the time of the survey did not benefit from the rural allowance scheme but their staffing levels continued to increase over the years instead of getting diminished due to the absence of the allowance as a pull factor to rural schools.

2. In both rural and urban schools in the zone under survey, the staffing levels had been increasing steadily since 2010, regardless of the rural schools having a perceived pull incentive known as rural allowance.

3. There was no remarkable increase in staffing levels in rural schools between 2009 and 2010 to reflect that an incentive had been introduced. There was equally no significant increase in staffing levels in the same schools between 2013 and 2014 to signify the $100 \%$ raise of the allowance.

The problem therefore is that staffing levels in rural schools do not seem to have improved significantly in spite of introducing the rural allowance and increasing it from $\mathrm{K} 5,000$ to $\mathrm{K} 10,000$ ( $\$ 7$ to 14 at the rate of MK 714 to $\$)$. The results of this survey may not reflect the general trend in all schools in the district. It was therefore important to involve more schools in Salima District to assess the impact of rural allowance on teacher retention and attraction to rural primary schools. This is an important study because it will draw direct experiences of teachers who are in a particular rural area. The assumption is that the study will reveal factors that may be location-specific so that stakeholders can take appropriate action.

\section{Major research question and specific objectives}

This study sought to answer the following major research question: To what extent do monetary incentives make primary school teachers to remain in rural schools and attract others from urban schools to rural schools of Salima District?

The following were the specific objectives of the study: i. To explore the extent to which rural allowance makes primary school teachers to remain in rural primary schools of Salima District. ii. To investigate the extent to which rural allowance attracts primary school teachers 
from urban to rural primary schools in Salima District. iii. To examine the degree to which other incentives are competitive to rural allowance in retaining and attracting teachers to rural primary schools.

\section{Theoretical framework}

This study was informed by the Three Cs Model. According to Cowan (2010), the Three Cs Model was proposed by Sher in 1983 and has three tenets, namely; Characteristics, Conditions and Compensation.

Cowan (2010) stipulates that one of the Cs in the Model represents characteristics of an individual. These characteristics are shaped by, among others, social background, sex, age, training, pre-service and personal experience of an individual which would have a bearing on the perceptions of a teacher about working in the rural areas. The second $\mathrm{C}$ represents conditions of service and working environment. Such conditions include recreational opportunities, housing, family and friends, among others. The model assumes that these conditions have a bearing on willingness of the teachers to continue working in a particular school. The model also assumes that less attractive working and living conditions would increase recruitment difficulties, turnover and attrition while decreasing retention. In the context of this research, schools situated in rural areas are perceived to have poor conditions due to absence of social amenities and require incentives to attract or retain teachers. The third C represents compensation which includes any financial incentives such as, rewards, benefits and opportunity costs such as the ability to earn money from alternative sources. The non-monetary incentives such as housing and promotion prospects are also forms of compensation.

\section{METHODOLOGY}

This study takes a quantitative approach to examine the extent to which rural allowance retains and attracts primary school teachers to rural schools in Salima District. The quantitative approach was adopted since the study tried to understand the perception of teachers on rural allowance effectiveness. The study population constituted all primary school teachers in the eleven education zones in Salima District. The EMIS data at Salima District Education Manager's Office indicated that there were 1825 qualified primary school teachers in the district.

The sample size in this study was determined based on published confidence and precision levels. According to Israel (2003), at precision level of $\pm 5 \%$ and confidence level of $95 \%$, when the study population is 1000 the sample size should be 286 . While for the same precision and confidence levels, when the study population is 2000 the sample size should be 333 . The sample of 333 comprising 250 teachers from rural schools and 83 teachers from urban schools was used since 1825 teachers was close to 2000 . The sample size of 333 teachers in this study provides assurance of $\pm 5 \%$ precision level and $95 \%$ confidence level which creates good generalizability of the results at district level.

Sex of the participants was used as a sampling frame for strata in the study. Three male teachers and two female teachers were randomly selected from their strata at each primary school. The male to female ratio of $3: 2$ was targeted since the study population constituted $58 \%$ males and $42 \%$ females which translates into the ratio of 3:2. However, in urban schools more females were selected than males as they were in the majority. There were 35 male and 48 female teachers who participated in the study in urban primary schools. Some schools contributed more than five teachers to cover-up for schools that had less than the required number of qualified participants but the male to female ratio was maintained in rural schools. Due to the limited numbers of the schools that do not receive the allowance, more than five participants were selected from such schools in order to achieve a meaningful representation of nonbeneficiaries in the study.

Data was collected using Likert type questionnaires. There were two sets of questionnaires. One questionnaire was administered to 250 teachers in rural primary schools and another type of questionnaire was administered to 83 teachers in urban primary schools.

\section{RESULTS}

This section presents the responses from primary school teachers regarding their perception of the rural allowance scheme. The data is presented according to the research objectives.

Please note that from the Likert scale tables, responses for 'strongly agree' and 'agree' are combined into 'agree' and the responses for 'strongly disagree' and 'disagree' are combined into 'disagree' in the analysis and discussion.

Research objective one: To explore the extent to which rural allowance makes primary school teachers remain in rural schools of Salima District.

The responses presented in this section provide insight into the extent to which rural allowance retains teachers in rural primary schools. Teachers in rural primary schools were asked if rural allowance motivates them to remain at their current school. Data shows that 122 $(48.8 \%)$ teachers disagreed and $116(46.4 \%)$ teachers agreed (Table 3 , Item 1). This shows that there is a motivational effect of rural allowance on close to half of 
the teachers teaching in rural primary schools but a significant $46.4 \%$ disagreed.

The study sought to find out if teachers felt that rural allowance had reduced the problems they faced at their work place (Table 3, Item 2). The majority of teachers $138(55.2 \%)$ disagreed while another group of teachers $92(36.8 \%)$ agreed that the allowance plays a role in reducing problems they face in rural schools. This may imply that a larger proportion do not appreciate the role of the rural allowance in alleviating their problems in the rural setting.

When the participant teachers were asked if they consider the rural allowance the major reason to make them refuse to relocate to another school that is not on the rural allowance scheme, an overwhelming majority $167(66.8 \%)$ disagreed (Table 3, Item 3). This could mean that there are other factors that are also critical in retaining teachers in rural schools.

Teachers were asked if they are satisfied with $\mathrm{K} 10,000$ as an incentive to make them remain in a rural school (Table 3, Item 4). This question was designed to assess the value teachers attached to the allowance. A large section of teachers $224(89.6 \%)$ disagreed compared with $17(6.8 \%)$ who agreed. The data shows that there is a general feeling among most teachers in rural schools that the amount paid as a compensation for teaching in remote schools is not enough and does not outweigh their problems.

Table 3. Influence of rural allowance on retention of teachers to rural primary schools.

\begin{tabular}{|c|c|c|c|c|c|c|c|c|c|c|c|}
\hline \multirow{3}{*}{\multicolumn{2}{|c|}{ Item }} & \multicolumn{10}{|c|}{ Responses } \\
\hline & & \multicolumn{2}{|c|}{$\begin{array}{l}\text { Strongly } \\
\text { disagree }\end{array}$} & \multicolumn{2}{|c|}{ Disagree } & \multicolumn{2}{|c|}{ Unsure } & \multicolumn{2}{|c|}{ Agree } & \multicolumn{2}{|c|}{$\begin{array}{l}\text { Strongly } \\
\text { agree }\end{array}$} \\
\hline & & $f$ & $\%$ & $f$ & $\%$ & $f$ & $\%$ & $f$ & $\%$ & $f$ & $\%$ \\
\hline 1 & $\begin{array}{l}\text { Rural allowance makes me } \\
\text { remain at my current school }\end{array}$ & 78 & 31.2 & 44 & 17.6 & 12 & 4.8 & 77 & 30.8 & 39 & 15.6 \\
\hline 2 & $\begin{array}{l}\text { Rural allowance has reduced the } \\
\text { problems I face at my work place }\end{array}$ & 83 & 33.2 & 55 & 22.0 & 20 & 8.0 & 62 & 24.8 & 30 & 12 \\
\hline 3 & $\begin{array}{l}\text { Rural allowance is the major } \\
\text { reason I cannot accept a posting } \\
\text { to an urban school. }\end{array}$ & 103 & 41.2 & 64 & 25.6 & 15 & 6.0 & 31 & 12.4 & 37 & 14.8 \\
\hline 4 & $\begin{array}{l}\text { I am satisfied with the } \mathrm{K} 10,000 \\
\text { allowance to remain in my } \\
\text { current rural school }\end{array}$ & 161 & 64.4 & 63 & 25.2 & 9 & 3.6 & 13 & 5.2 & 4 & 1.6 \\
\hline
\end{tabular}

Research objective two: To investigate the extent to which rural allowance attracts primary school teachers from urban to rural schools in Salima District.

There is strong indication that teachers in urban schools wish to benefit from the rural allowance scheme. This is demonstrated clearly when selected teachers in urban primary schools were asked if they wish to be among the beneficiaries of rural allowance. The majority of the respondents (88\%) agreed (Table 4 , Item 1$)$.

When asked if they consider rural allowance as the major reason they would accept a posting to a school in a remote area, $43.4 \%$ disagreed, while $53 \%$ agreed (Table 4, Item 2).

As per Table 4, Item 3, the study sought the opinion of teachers in urban schools if rural allowance is the best strategy to improve staffing levels in rural schools. A larger section of teachers 46 (55.4\%) agreed compared with 29 (35\%) who disagreed.

Research objective three: To examine the degree to which other incentives are competitive to rural allowance in retaining teachers to rural schools.
The responses provided in this section give a reflection of the power of rural allowance over other incentives that are or may be provided to teachers in rural schools. Teachers in rural primary schools were asked if the availability of a decent house for accommodation makes them to remain in rural schools more than does the rural allowance. With reference to Table 5, Item 1, data shows that 191 respondents (76.4\%) disagreed against 52 (20.8\%) who agreed.

Teachers teaching in urban schools were also asked if the availability of a decent house for accommodation would attract them to go to a rural school more than rural allowance. At least 31 (37.3\%) disagreed, while a good number of them $50(60.3 \%)$ agreed (Table 6, Item 1).

The study tried to ascertain if availability of land for farming makes teachers to remain in rural schools more than rural allowance. As reflected on Table 5, Item 2, a large percentage of the teachers $(69.6 \%)$ disagreed compared with $22.8 \%$ who agreed. Rural allowance was also compared with the availability of land for farming as regards attracting teachers from urban schools to rural schools. Table 6, Item 2 indicates that most teachers 49 $(59.1 \%)$ disagreed with the statement that availability of 
Table 4. The role of rural allowance in attracting teachers from urban to rural primary schools.

\begin{tabular}{|c|c|c|c|c|c|c|c|c|c|c|c|}
\hline \multirow{3}{*}{\multicolumn{2}{|c|}{ Item }} & \multicolumn{10}{|c|}{ Responses } \\
\hline & & \multicolumn{2}{|c|}{$\begin{array}{l}\text { Strongly } \\
\text { disagree }\end{array}$} & \multicolumn{2}{|c|}{ Disagree } & \multicolumn{2}{|c|}{ Unsure } & \multicolumn{2}{|c|}{ Agree } & \multicolumn{2}{|c|}{$\begin{array}{l}\text { Strongly } \\
\text { agree }\end{array}$} \\
\hline & & $f$ & $\%$ & $f$ & $\%$ & $f$ & $\%$ & $f$ & $\%$ & $f$ & $\%$ \\
\hline 1 & $\begin{array}{l}\text { I wish to be one of the beneficiaries of } \\
\text { rural allowance }\end{array}$ & 5 & 6.0 & 1 & 1.2 & 4 & 4.8 & 12 & 14.5 & 61 & 73.5 \\
\hline 2 & $\begin{array}{l}\text { Rural allowance is the major reason I } \\
\text { would accept a posting to a school in } \\
\text { remote area }\end{array}$ & 25 & 30.1 & 11 & 13.3 & 3 & 3.6 & 17 & 20.5 & 27 & 32.5 \\
\hline 3 & $\begin{array}{l}\text { Rural allowance is the best strategy to } \\
\text { improve staffing levels in rural schools }\end{array}$ & 18 & 21.7 & 11 & 13.3 & 8 & 9.6 & 20 & 24.1 & 26 & 31.3 \\
\hline
\end{tabular}

Table 5. Influence of other incentives on teacher retention in rural schools in comparison with rural allowance.

\begin{tabular}{|c|c|c|c|c|c|c|c|c|c|c|c|}
\hline \multirow{3}{*}{\multicolumn{2}{|c|}{ Item }} & \multicolumn{10}{|c|}{ Responses } \\
\hline & & \multicolumn{2}{|c|}{$\begin{array}{l}\text { Strongly } \\
\text { disagree }\end{array}$} & \multicolumn{2}{|c|}{ Disagree } & \multicolumn{2}{|c|}{ Unsure } & \multicolumn{2}{|c|}{ Agree } & \multicolumn{2}{|c|}{$\begin{array}{c}\text { Strongly } \\
\text { agree }\end{array}$} \\
\hline & & $f$ & $\%$ & $f$ & $\%$ & $f$ & $\%$ & $f$ & $\%$ & $f$ & $\%$ \\
\hline 1 & $\begin{array}{l}\text { Availability of a decent house for } \\
\text { accommodation makes me to remain } \\
\text { in my current rural school more than } \\
\text { rural allowance }\end{array}$ & 130 & 52.0 & 61 & 24.4 & 7 & 2.8 & 37 & 14.8 & 15 & 6.0 \\
\hline 2 & $\begin{array}{l}\text { Availability of land for farming makes } \\
\text { me remain in my rural school more } \\
\text { than rural allowance }\end{array}$ & 103 & 41.2 & 71 & 28.4 & 19 & 7.6 & 35 & 14.0 & 22 & 8.8 \\
\hline 3 & $\begin{array}{l}\text { Availability of enough teaching and } \\
\text { learning resources in a rural school } \\
\text { would make me remain there more } \\
\text { than rural allowance }\end{array}$ & 113 & 45.2 & 72 & 28.8 & 20 & 8.0 & 34 & 13.6 & 11 & 4.4 \\
\hline 4 & $\begin{array}{l}\text { Good school management makes me } \\
\text { remain in my rural school more than } \\
\text { rural allowance. }\end{array}$ & 55 & 22.0 & 70 & 28.0 & 45 & 18.0 & 56 & 22.4 & 24 & 9.6 \\
\hline 5 & $\begin{array}{l}\text { Good relationship with the Parents } \\
\text { and Teachers Association makes me } \\
\text { remain in my rural school more than } \\
\text { rural allowance }\end{array}$ & 77 & 30.8 & 76 & 30.4 & 30 & 12.0 & 48 & 19.2 & 19 & 7.6 \\
\hline
\end{tabular}

land for farming would attract them to go to a rural school more than rural allowance.

When asked a hypothetical question if availability of enough teaching and learning resources in a rural school would make teachers to remain there more than the rural allowance, the overwhelming majority of teachers (74\%) disagreed (Table 5, Item 3 ). The availability of teaching and learning materials does not seem to play a significant role in making teachers remain in the rural schools. The study further inquired from teachers in urban schools if availability of enough teaching and learning resources in rural schools would attract them to go there more than rural allowance. The majority of the teachers (66.3\%) disagreed (Table 6, Item 3 ). In the opinion of urban teachers, adequate teaching and learning resources have little appeal to make them go to rural schools.

Teachers were also asked if good school management and good relationship between management and the 
Table 6. Influence of other incentives on teacher attraction in comparison with rural allowance.

\begin{tabular}{|c|c|c|c|c|c|c|c|c|c|c|c|}
\hline \multirow{3}{*}{ Iten } & & \multicolumn{10}{|c|}{ Responses } \\
\hline & & \multicolumn{2}{|c|}{$\begin{array}{l}\text { Strongly } \\
\text { disagree }\end{array}$} & \multicolumn{2}{|c|}{ Disagree } & \multicolumn{2}{|c|}{ Unsure } & \multicolumn{2}{|c|}{ Agree } & \multicolumn{2}{|c|}{$\begin{array}{c}\text { Strongly } \\
\text { agree }\end{array}$} \\
\hline & & $f$ & $\%$ & $f$ & $\%$ & $\mathbf{f}$ & $\%$ & $f$ & $\%$ & $\mathbf{f}$ & $\%$ \\
\hline 1 & $\begin{array}{l}\text { Availability of a staff house would attract } \\
\text { me to go to a rural school more than } \\
\text { rural allowance. }\end{array}$ & 22 & 26.5 & 9 & 10.8 & 2 & 2.4 & 16 & 19.3 & 34 & 41.0 \\
\hline 2 & $\begin{array}{l}\text { Availability of land for farming would } \\
\text { attract me to go to a rural school more } \\
\text { than rural allowance. }\end{array}$ & 32 & 38.6 & 17 & 20.5 & 20 & 24.1 & 6 & 7.2 & 8 & 9.6 \\
\hline 3 & $\begin{array}{l}\text { Availability of enough teaching and } \\
\text { learning resources in a rural school } \\
\text { would attract me to go there more than } \\
\text { rural allowance. }\end{array}$ & 22 & 26.5 & 33 & 39.8 & 9 & 10.8 & 8 & 9.6 & 11 & 13.3 \\
\hline 4 & $\begin{array}{l}\text { Good school management would attract } \\
\text { me to go to a rural school more than } \\
\text { rural allowance. }\end{array}$ & 21 & 25.3 & 33 & 39.8 & 8 & 9.6 & 14 & 16.9 & 7 & 8.4 \\
\hline 5 & $\begin{array}{l}\text { Good relationship with the Parents and } \\
\text { Teachers Association would attract me } \\
\text { to go to a rural school more than rural } \\
\text { allowance. }\end{array}$ & 27 & 32.5 & 25 & 30.1 & 10 & 12.0 & 12 & 14.5 & 9 & 10.8 \\
\hline
\end{tabular}

Parents and Teachers Association (PTA) make them to remain in their rural schools more than rural allowance. The results in Table 5, Item 5 show that $50 \%$ disagreed compared with $32.0 \%$ who agreed. On Item 6 of Table 5 , $153(61.2 \%)$ teachers disagreed while 67 teachers $(26.8 \%)$ agreed. For similar items in Table 6 (item 5), most participants from urban schools $(65.1 \%)$ disagreed that they would be attracted to go to rural schools because of good school management. They also disagree $(62.6 \%)$ that they would be willing to work in rural schools if the relationship between the school management and the PTA was sound.

\section{DISCUSSION}

The study was designed to find out if the rural allowance attracted teachers to and retained them in rural schools. The research also sought to investigate if there are other incentives that may be critical in retaining teachers in rural schools. The discussion is structured according to the research objectives so that it deals with one theme at a time.

Research objective one: To explore the extent to which rural allowance makes primary school teachers to remain in rural schools of Salima District.

The overall picture that Table 3 paints is that rural allowance is not good enough for the teachers experiencing hardship in rural schools. On introducing the rural allowance, MoEST had anticipated high morale amongst teachers that would be attracted to go to rural schools and that those already in rural schools would prefer to remain there. Less than $50 \%(46.4 \%)$ of the teachers in rural schools agreed that the rural allowance was significant enough to make them remain in rural schools, whilst $48.8 \%$ of them indicated that the allowance was not attractive enough (Table 3, Item 1). Responding to a statement if the rural allowance was significant enough in alleviating their hardship, $55.2 \%$ of them disagreed with the statement. Over $66.8 \%$ of the respondents also disagreed that the rural allowance was the major reason why they would not want to transfer to an urban school. Further, an overwhelming $89.6 \%$ of the respondents disagreed that the current $\mathrm{K} 10,000$ rural allowance was satisfactory.

Initial Primary Teacher Education program (IPTE) started in 2005 to train teachers that would be deployed in the rural schools. Although these teachers were meant to go to rural schools, it is not clear if everyone was indeed posted to a rural school. Even if all had been posted to rural schools, it is unlikely that all of them are still in rural schools. It is likely that a percentage of the teachers from the IPTE program may have gone to urban schools for a range of reasons, such as the need to work near a good health facility or to follow a spouse who is in 
town.

Assuming that a significant percentage of the IPTE teachers are still in rural schools, they have probably added a considerable percentage to the respondents that disagreed with the significance of the rural allowance. If this is indeed the case, then the contribution of the IPTE program to staffing rural schools may only be cosmetic because teachers in rural schools will continue to look for excuses to leave for urban schools. It therefore appears that increasing the rural allowance of $\mathrm{K} 10,000$ is urgent. To what amount it must increase, may have to be investigated and negotiated so that the ideas of the rural teachers are considered as a way of advancing ownership of the methods of arriving at the amount of the rural allowance. This is in fact what Vegas and Umansky (2005) advance that teachers may choose to remain in rural schools depending on how the incentive is designed and implemented after thorough negotiations.

It is important that the teachers affected by the hardship in rural schools should be involved in the design of the allowance. A similar program of retaining and attracting teachers to rural schools in Lesotho faced similar challenges of teachers not wanting to remain or go to rural schools because the allowance was viewed as not attractive enough (Mulkeen and Chen, 2008). With the advent of human rights, it can be expected that the affected teachers would be uncomfortable with an arrangement that has been imposed on them.

There are various other factors that may influence a negative response to rural allowance. According to Cowan (2010), dissatisfaction with an incentive may emanate from compromised value attached to it. As per principles of the Three Cs Model, teachers view rural allowance as insufficient compensation for being exposed to 'harsh' conditions in rural areas. It is evident that economic hardships teachers encounter in rural schools are daunting and outweigh the allowance as compensation. However, when compared with $10 \%$ retention rate in Gambia and the $46.4 \%$ retention rate in Salima District could be considered remarkable.

Devaluation of the currency may also have affected the value teachers attach to the allowance resulting in a negative response from teachers. Since the introduction of the allowance, the Malawi Kwacha devalued several times between 2010 and 2015 although the allowance had only been revised upwards once. Such stagnation in revision of the allowance may have diminished its value.

It is also possible that the teachers in rural schools are dissatisfied with the rural allowance because of the perceived lost opportunities that are usually found in urban settings. There are opportunities of better resourced schools for their children and dependents; part-time teaching for additional income; and opportunities for a spouse complementing family income. Such opportunities can outweigh the $\mathrm{K} 10,000$ rural allowance.

The conclusion is that rural allowance of $\mathrm{K} 10,000$ does not make primary school teachers in the rural areas of Salima District want to remain in those schools because it is viewed as insignificant when it is weighed against the hardship they face and the perceived lost opportunities that may be available in urban centres.

Research objective two: To investigate the extent to which rural allowance attracts primary school teachers from urban schools to rural primary schools in Salima District.

The overarching picture coming from Table 4 is that the teachers in urban schools are quite attracted by the current rural allowance. If $88 \%$ (Table 4 , item 1 ) of sampled urban teachers expressed interest to be on the rural allowance scheme, the understanding is that they are prepared to go to rural schools. Table 4, item 2 shows that $53 \%$ of the urban teachers consider the allowance as the major reason they would relocate to a rural school. Further, $55.4 \%$ of the urban teachers agreed that the allowance is the best strategy to improve staffing in the rural schools (Item 3).

Given that a study conducted in Namibia did not show any evidence that hardship allowance attracted urban teachers to rural schools (UNICEF, 2014), it appears that the urban teachers in Malawi may be exaggerating the value of the allowance which their counterparts in rural schools condemned as unsatisfactory (Table 3, item 4). However, attracting such a proportion of teachers would be a significant step in increasing staffing levels in rural schools.

It is important to note that some urban school teachers may have responded to the statements out of inadequate information about the buying power of the allowance. If the teachers had clearly known that the allowance is not of much value in alleviating hardship in rural schools, they would probably refuse to go to such schools.

Like in Lesotho and Namibia, schools should be allowed to hire teachers. Such an arrangement would make teachers that are interested to go to rural schools commit themselves to such schools (Mulkeen and Chen, 2008; UNICEF, 2014).

The government could also make a hybrid system of rural allowance by building in what Gambia and Mozambique do in recognising the degree of ruralness. There are places in Malawi that are so difficult to reach that truly deserve extra incentives to attract teachers to work there. It may be expensive for government but this is what needs to be done if the country must talk with moral authority about providing access to quality education to all Malawians.

What stands out from the discussion is that teachers in urban schools are attracted by the rural allowance to teach in rural schools. What is not clear is whether they have enough knowledge of the general hardship in the rural areas that the rural allowance is designed to alleviate. 
Research objective three: To examine the degree to which other incentives are competitive to rural allowance in retaining and attracting teachers to rural primary schools.

The general picture that Table 5 revealed is that teachers in the rural schools of Salima disagreed that the mentioned incentives are good enough to make them remain in the rural schools. Table 6 shows that in addition to the rural allowance, the teachers in urban schools were attracted only by the idea of having decent accommodation. Like the teachers in the rural schools, they were not attracted by the mentioned incentives.

It should be noted that the statements in Tables 5 and 6 were based on a hypothetical situation. The idea was to find out teacher opinions if the situation in schools had been ideal. The purpose was to know the incentives that would attract teacher most so that MoEST can implement them.

\section{Incentives for rural and urban primary school teachers}

This study revealed that the majority of the teachers who teach in rural schools disagreed that any of the mentioned incentives (accommodation, land for cultivation, enough teaching and learning materials, good school management and good relationships) would make them remain in the rural schools (Table 5). Their counterparts in urban schools also disagreed that they would be attracted by the same incentives, except accommodation (Table 6).

Teachers in rural schools contradict Mulkeen and Chen (2008) that housing has a stronger bearing on teacher retention than financial incentives. Further, housing is identified as one of the most frequently used incentives to attract and retain employees to a particular setting. In the case of teachers in many rural schools in Malawi, the poor quality of housing may account for their views. Housing in many primary schools is so poor that it could easily act as a push factor to urban schools. On the other hand, the teachers in urban schools may be attracted to housing perhaps because they may not really know the quality of housing they are likely to live in.

Both groups of respondents disagreed that they would be attracted by the availability of land to grow crops. In the Malawi context, land is usually highly valued for agricultural purposes. The assumption is that if one owns land, one would be able to grow food and even sell some for extra income to support their family. It is therefore surprising that owning a piece of land is not valued. The most extensively grown cash crop in Salima District is cotton. Recently, the crop has fetched low prices on the market and this may have made teachers to lose interest in agriculture.

Both groups disagreed that adequate teaching and learning materials would attract them to remain or go to a rural school. Teaching and learning materials for primary schools in Malawi are distributed from central government pool based on school enrollment. Therefore, teachers may be knowledgeable of the fact that there is not much difference in availability of the materials between urban and rural schools to make them prefer one over the other. In addition, given the sudden increase in primary school student population as a result of introducing a Free Primary Education policy in 1994, it is unlikely that there are adequate teaching and learning resources in primary schools. In other words, the teachers would find it difficult to go to schools with inadequate resources.

It has been observed that poor leadership and relationships in schools scare away teachers (Simon and Johnson, 2013). Items 5 and 6 in Tables 5 and 6 show that teachers in rural and urban schools disagreed that good school management and teacher-PTA relationships would make them remain in or go to rural schools in Salima District. It is rather surprising that the two aspects do not make teachers remain in the rural schools or get attracted to more to rural schools. Unlike in other parts of the World, teachers in Salima place so much value on the allowance that other incentives do not matter.

The overall picture with regard to objective 3 is that none of the other incentives are attractive enough to make rural teachers remain in the rural areas or attract the urban teachers to go to rural schools. A point to note is that even the urban teachers who were attracted by the rural allowance, were not attracted by the other incentives.

\section{CONCLUSION}

This study attempted to find out the extent to which monetary incentives on teacher retention in and attraction to rural primary schools in Salima District. The study established that the current amount of rural allowance is not considered attractive enough to make teachers remain in or go to rural schools. It was also clear that rural allowance alone was not a satisfactory incentive. The government should develop a package of incentives for rural schools that includes additional incentives, and takes into account the different degrees of ruralness. Further, school authorities should be allowed to recruit persons that would be interested to teach in rural schools. The concerns of teachers regarding the need for tailor-made and attractive conditions to alleviate the hardship they experience in rural schools sound so genuine and urgent that they must be addressed if the supply of teachers to such schools is to improve.

\section{Limitation of the study}

The study did not analyse the data according to gender. It is likely that a high proportion of the respondents in the 
urban schools may have been males who may be more prepared to go to rural schools. The same may be true that most of the respondents in the rural schools who want to leave may have been female teachers who tend not to cope well in isolated rural settings (Mulkeen and Chen, 2008).

The questionnaire should have included questions to find out if age was a factor in preference for urban schools or not. For example, it may be the case that relatively younger teachers would dislike rural schools more than older teachers.

\section{RECOMMENDATIONS}

1. It is clear that any intervention that targets only one challenge may not be adequate to realise meaningful impact on increasing teachers in rural schools. Intervention should include a package of incentives that are meant to cushion particular hardship.

2. Literature observes that urban areas have qualified teachers who are unemployed, while rural areas have unfilled posts (Mulkeen and Chen, 2008). Government should develop packages of attractions that should target the unemployed teachers and should include paying graduated rural allowances so that those in very difficult environments receive higher allowances.

3. The government should target residents of a particular rural area for training so that they can return to their home areas. In addition, such teachers should also enjoy rural allowance and other similar incentives. It is hoped that they will have commitment to their home schools and be useful role models.

4. The government should permit schools to head-hunt and recruit teachers that are interested to teach in rural schools.

5. To mitigate loneliness, the government should consider deploying at least two teachers who are friends to a particular school. The rationale is to create a team that can support each other in times of need (Mulkeen and Chen, 2008).

6 . The study recognizes that the government may be challenged in financing such an approach. The study recommends a separate study to address such concerns.

\section{REFERENCES}

Cowan, T. H. (2010). Teacher perspectives on factors that affect teacher attrition and retention in rural middle schools of North Carolina. Western Carolina University.

Israel, D. (2003). Determining sample size. University of Florida.

Kulemeka, A., and Ndalama, C. (2013). Lilongwe Rural East teachers cry for hardship allowances. Lilongwe: Malawi News Agency.

Malawi Government (2011). Annual report. Lilongwe: Ministry of Education Science and Technology.

Miller, L. C. (2012). Working paper: Understanding rural teacher retention and the role of community amenities. University of Virginia. http://curry.virginia.edu/research/centers/cepwc/publications.
Mulkeen, A., Chapman, D. W., Dejaeghere, J. G., and Leu, E. (2007). Recruiting, retaining and retraining secondary school teachers and principals in sub-Saharan Africa. Washington: World Bank. http://www.worldbank.org.

Mulkeen, A. (2005). Teachers for rural schools: A challenge for Africa. Washington DC: The World Bank.

Mulkeen, A., and Chen, D. (2008). Teachers for rural schools experience in Lesotho, Malawi, Mozambique, Tanzania and Uganda. Washington DC: The World Bank. http://www.worldbank.org.

Pugatch, T., and Schroeder, E. (2013). Incentives for teacher relocation: Evidence from the Gambian hardship allowance. Oregon State University.

Simon, N.S., and Johnson, S.M. (2013). Teacher turnover in highpoverty schools: What we know and can do: Project paper. Harvard Graduate School of Education.

UNICEF (2014). The impact of incentives for the recruitment and retention of qualified teachers in Namibia's remote schools. https://www.unicef.org.

Wallace, C., and Sartono, A. (2010). Teacher attrition in Sub-Saharan Africa: The neglected dimension of the teacher supply challenge. Addis Ababa: International Task Force on Teachers for Education for All.
Citation: M wenda, D. B., and Mgomezulu, V. Y. (2018). Impact of monetary incentives on teacher retention in and attraction to rural primary schools: Case of the rural allowance in Salima District of Malawi. African Educational Research Journal, 6(3): 120-129. 